\title{
Adaptation Strategies to Environmental Change in the Nigeria's Section of the Chad Basin
}

\author{
A. Dami \\ Department of Geography, University of Maiduguri, Nigeria \\ Tel: 234-706-953-5302Ｅ-mail: tonidamy@yahoo.com \\ F. A. Adesina \\ Department of Geography, Obafemi Awolowo University, Ile-Ife, Nigeria \\ Tel: 234-803-719-3141_E-mail: Faadesin@yahoo.com \\ S. S. Garba \\ Department of Civil and Water Resources Engineering, University of Maiduguri, Nigeria \\ Tel: 234-708-979-8044Ｅ-mail: sam.garba@yahoo.com
}

Received: July 16, 2010 Accepted: August 3, 2010 doi:10.5539/jgg.v3n1p22

\begin{abstract}
The environmental change manifested in terms of drought and desertification in the Lake Chad basin area is characterised by the drastically reduction in the volume of the water in the basin, with serious consequences both at the local and global environment. This therefore demands an immediate attention as such change can no longer sustain the livelihood of the people of the area. A questionnaire was administered to collect primary data on the socio-economic activities and drought coping strategies of the people living in the locations of the Lake Chad basin (the Baga in the north of the basin and Southern Chad project around Marte in the south of the basin). Five communities were randomly selected from the 21 in Baga and another 5 from the 24 in Marte. The populations of these communities were between 2000 and 2500 . Thus a sample size of about $2.5 \%$, (that is 500 people) was taken. The strategies with which local communities are responding to the increasingly unfavourable environment of the basin were evaluated. These were done with a view to providing an understanding of the dynamics of land and water uses in the area.
\end{abstract}

Keywords: Adaption, Water, Lake Chad basin, Environment change, Nigeria

\section{Introduction}

One of the most significant facts that became well appreciated at the turn of the last century was that the environment is changing far more dramatically and significantly than it had ever been thought of. The nature of this environmental change varies in time and space. In general, changes have almost always led to degradation in the quality of environmental parameters (such as forestry and soil quality). At the dawn of the $21^{\text {st }}$ Century, the cumulative and markedly progressive human-induced changes in atmospheric and biospheric processes have resulted in remarkable and probably irreversible impacts on climate and life forms on the planet. Consequently, Global Environmental Change (GEC) has become a key issue in developmental discourse and has taken a central stage in several international meetings (IPCC, 2001).

About half a century ago, the Lake Chad was one of the largest inland water bodies in the world. In 1963, it covered a surface area of about 25,000 square kilometres (Coe, 2001). However, a fairly recent assessment indicates that it has reduced to less than 20 percent of that size as revealed from satellite imageries reported by NASA (2001) (Figure 2). This implies that extensive ecological change had occurred in the areas.

The reduction in the size of the lake is associated with two main factors: climate change and human demand for water. The climatic factors related chiefly to the declining frequency and volume of rainfall received within and outside the basin (since the lake is also fed by rivers and streams outside the basin). The human factors are mainly related to land use and are driven by an increasing demand for water even as its supply is decreasing. 
Drought and Desertification becomes imminent in this area when vegetation in particular gets degraded or completely removed due to human activities particularly grazing by animals. Overgrazing results in changes in species composition and density of plant cover (Perkin \& Thomas, 1993). The process is also driven by climatic behaviour particular rising temperature and decreasing rainfall. The reduced plant cover leads to the lowering of soil organic matter and makes its susceptibility to erosion (Young, 2000). This would ultimately result in virtually barren land (Duraiappah, 1996).

The menace of drought and desertification in the basin had remarkable impacted the socio-economic lives of the people in the region. This is because the major economic activities in basin are fisheries, rain fed and irrigated farming which solely depends on the weather (LCBC, 2008). And since the area had suffered long term drought and desertification, there is a continuous negative impact on the habitat (Thambyaphillay, 1987). This study therefore attempts to characterize the socio-economic milieu of the study area in order to describe how the local people cope with extreme climatic events (largely drought related phenomenon). While there are many possible adaptation options for responding to climate change in this region as reported in Adesina et al. (2009) and Workineh (2007). The specific objective of the study is to evaluate the strategies with which local communities are responding to the increasingly unfavourable environment of the basin.

\section{The study area}

The Lake Chad basin is located approximately between latitude $12^{\circ} \mathrm{N}$ and $14^{\circ} 30^{\prime} \mathrm{N}$ and Longitudes $13^{\circ} \mathrm{E}$ and $15^{\circ} 30^{\prime} \mathrm{E}$ (see Figure 1) parts of four West African countries namely Chad, Cameron, Nigeria and Niger. In Nigeria's territory the basin covers an area of approximately $200,000 \mathrm{~km}^{2}$ with $720 \mathrm{~km}^{2}$ attenuation westwards from the shores of the lake and a north-south width of about $300 \mathrm{~km}$ (Thambyahphillay, 1987). The Lake Chad basin comprises five bioclimatic zones, namely: Saharan, sahelo-saharan, sahelo-sudanian, sudano-sahelian and sudano-guinea ecological zones (LCBC, 2007). The south-west humid Atlantic (monsoon) and the north-east Egyptian hot and dry (harmattan) currents influence the climate and consequently the ecological zonation of the basin. The sudano-guinean climate in the south for example has average annual rainfall of over 950 millimeters, a rainy season of six to seven months (May-November) with an average annual temperature at Sarh (formerly Fort Archambault in Chad) of $28^{\circ} \mathrm{C}$ (absolute minimum $10^{\circ} \mathrm{C}$, absolute maximum $45^{\circ}$ ) and annual Piche-recorded evaporation of $2027 \mathrm{~mm}$ in 1961. During the winter months the cool, dry, dust-laden "hamattan" blows from the Saharan in the north, bringing low humidity, cool nights and warm days. In summer months, moisture-laden winds blows from the Gulf of Guinea in the south bring high humidity, rains, and more uniform diurnal temperature. The monsoon advances from the south, so that rains start earlier, are heavier and last longer in the southwards, although in general there is high spatial and temporal variability over the entire area. The terrain of the study area is generally flat with a few shallow depressions and a few widely scattered elevated spots. The resulting surface drainage density is low (LCBC, 2007).

\section{Methodology}

The data sets design for this study was generated from the socio-economic survey conducted between December 2007 and April 2008. The areas demarcated covered the two major projects sites located within the basin namely the Baga Polder Project (BPP) located in Baga area in the western part of the basin and Southern Chad Irrigation Project (SCIP) around New Marte in the southern part of the basin (Figure 1). These two areas were chosen because they were used by Lake Chad Basin Commission for irrigation and fisheries and therefore are suitable as controls for the study (LCBC, 2005).

Ten communities were randomly selected from the list of all communities located within the Baga and New Marte areas. The list of the communities was obtained from the Lake Chad Basin Commission. In each of the ten communities, all households were listed in the sequence of their geographic occurrence in the communities and 50 of them were picked using the systematic random sampling procedure. This exercise was conducted with the assistance of Borno State Lake Chad Basin staff from their outreach stations located in Baga and New Marte area. The head each household or his representative of the houses selected were interviewed using the same set of questions. The questions were asked by the researcher and his assistance. There are 65 questions in all divided in four sections: (1) personal data which includes name, sex, age, marital status and educational background; (2) Socio-Economic characteristics which asked questions on the occupation (rainfed farming, irrigation and fishery), factors affecting economic activities, use of the lake, income, 24 questions; (3) Coping strategies which related to how the people cope when crop failed, the factors that help them prepare for crop failure, and whether there are help from government and NGO; and (4) Awareness on Inter-basin water transfer which included questions on whether they are aware of inter-government activity to restore the level of water in the lake to its previous status. 
The data from the household survey were coded electronically and analysed. The frequencies of the responses were used to explore the socio-economic characteristics in relation to local people's coping strategies against adverse climatic events.

\section{Results and discussion}

The result of the interview conducted during the study is outlined below. Most of the respondent are from age 30 years and above and are farmers and fishermen. These results tell us how people are responding to the dwindling size of the Lake Chad as reported by NASA (2001). Generally life is difficult for human and animal survival in the area. Hence the reducing water body can no longer sustain the livelihood of the inhabitants of the region, thus forcing the people to device strategies to cope with this changing environment.

\subsection{Source of water for farming}

Water is the most important factor of survival in the study area as far as farming and livestock keeping is concerned. This is because these activities are dependent on large supply of water. It is thus useful to find out how people living in the area secure water for farming. Table 2 shows that about a quarter of respondents depended on rainfall alone for farming while less than a tenth depended on water from the lake only. A large proportion, about seven-tenths relied on both rain and the lake. A small proportion of less than $2 \%$ dig well to source water for farming.

The proportion depending on rain alone (about $25 \%$ ) is significant. This means that when rain fails totally at least a quarter of the population is completely incapacitated. Since the dams also depend on water from the rains, the number affected by poor rain is in fact larger. Provision of water thus remains a critical issue for survival in the region.

It is important to note that only about $2 \%$ tapped underground water for farming. This suggests that the underground source of water which is very important in an environment like this is highly underutilised. This may be in part because it is expensive to dig deep wells that are can yield large quantity of water that may be required for irrigation. To provide some succour to the local people, government and development agencies could invest in the provision of deep wells in more locations in the region.

\subsection{Seasonality in the usage of water}

The demand for water in the study area could also be measured by determining when water is needed for various activities. As expected, people need water throughout the year i.e. during the wet and dry season (Dami, 2008). Only a little above one-tenth needs water during the rains alone (Table 3). This proportion may be the bulk of those who migrate out of the region temporarily during the dry season.

\subsection{Coping strategies adopted in adverse climatic conditions}

Although the environment of the basin has changed significantly (the level of water, aridity of the soil and the disappearance of some plant and animal species) in the last couple of decades as demonstrated in Dami (2008), there are still large settlements in the area. These settlements have existed largely because of the varieties of coping strategies they adopted in the face of difficult environmental conditions (Adger, et al 2003; Nyong et al. 2007). This study has attempted to identify the coping strategies that have been adopted over time.

Table 1 shows the various types of adaptation used by local people in coping with the harsh conditions resulting from the declining volume of water in the lake and basin in general which agrees with Workineh (2007). A little more than one-fifth of the respondents $(21.9 \%)$ engaged in rearing of animals to cope in order to with crop failure. Almost one-fifth (17.8\% and 17.2\%) involved in activities like buying and selling of non-agricultural products and fishing respectively. About one in twenty persons (4.1\%) migrate to nearby countries in search for food as supported by LCBC (2007), while a larger proportion (24.7\%) relies on the food they stored during good harvest. Closed to a tenth (7.5\%) said that they did nothing to cope with adverse conditions while $6.9 \%$ have other means of coping e.g. engaging in handcraft such as weaving and mat making, hunting of wild animals and selling of fuel wood (Dami, 2008).

Quite clearly the inhabitants of the area have developed survival strategies to live with the unfriendly arid conditions of the study area. None of these strategies however addressed the fundamental issue of decline in water supply. People simply seem to cease carrying out activities that require water. It could safely be said that if the conditions deteriorated further, more and more people will move out of the area into the other parts of sub-Saharan Africa with all the potential problems that may attend this decision (LCBC, 2007; 2008 and Workineh, K. 2007). This observation underscores the need to intensify the efforts by the LCBC member states (Nigeria, Niger, Chad Republic, Cameroun, Central African Republic and Sudan) to recharge the water from 
Ubangui river from Congo to the lake. Apart from meeting the needs of the local people, it will also prevent the conflicts that are usually associated with migration in the region.

\subsection{Support in times of crop failure}

Less than a quarter of the respondent indicated receiving some form of assistance in coping with the hostile environment of the area when crop failed (Table 4). Most of the inhabitants dealt with the situation on their own. The main sources of support other than the government come from the churches and mosques.

\subsection{Government intervention programme}

From Table 5, more than three-fifths (61\%) of the respondents are aware of government response action to mitigate the problem in the area. About half of them heard it from the radio, while less than a tenth $(7.1 \%)$ heard it from other persons. Close to a third got the information from other sources such as newspapers and televisions. To a reasonable extent, the communities are well sensitized about government intentions for the development of the basin including the proposed inter-basin water transfer. Radio comes out as a strong vehicle for reaching the people in the area. It can probably be relied upon to reach communities on the various development programmes (Dami 2008).

Still on awareness, a larger proportion of the respondents $(61 \%)$ believed that the Nigerian Government would pay for the water transfer project while close to a fifth believed that foreign donors will pay (Table 5). These responses underscore the expectations of the people from government. Government needs to rise up to this challenge. There is also the need to sensitize the people to know that the environmental issues transcend national boundaries. This is to encourage cooperation on issues that may require collaboration with other countries to share in the resources of the basin.

\section{Conclusion}

As presented above, the analysis of some important parameters with respect to socio-economic characteristics of the study area shows important findings.

First, the analysis shows that the Lake Chad basin is generally less suitable for socio-economic activities and the people living in the area have weak adaptive capability to the harsh environment as supported by Workineh (2007). As earlier noted, there is very little adaptation practices that related to increasing the individual's access to water or extending farming activities beyond the limits set by the rains. What appeared to be the most prominent practice is to withdraw from the environment when conditions reached the extremes in the long dry season. This practise also applies to individuals who had large storage in times of good harvest. Large storage could only help if the period of drought does not persist for too long.

It is suggested that the burden of effective adaptation in this environment is probably beyond the individual and the government needs to continue to pursue the environmental restoration efforts as well as focus on tapping underground water through boreholes for population centres in the region.

It is important that local people can appreciate and indeed are anticipatory of the effort to move water into the basin. Most people would like the project to take off as soon as possible but suggested that flooding could happen as a result of the movement of water into the area. The fear may be well founded except necessary precautions are taken. It is important that appropriate studies be conducted about the nature of the focal area where the transferred water will be deposited as well as the volume of water that can be moved per unit of time. Other impacts such as increased breeding opportunities for mosquitoes and other disease vectors must also be factored into the planning of the water transfer.

\section{Reference:}

Adger, W. N., Huq, S., Brown, K., Conway D. \& Hulme, M. (2003). Adaptation to climate change in developing world. Progress in development studies, 3(3), 179-195. doi:10.1191/1464993403ps060oa, http://dx.doi.org/10.1191/1464993403ps060oa

Adesina, F.A., Odekunle, T.O., Ajayi, O., Babatemihen, O., Dami, A., Sanni, M., Aloba, O., Ambo, M. \& Adetiloye, O.T. (2009). Adaptation strategies of action for Nigeria: A working Document prepared for Special Climate Change. Unit of Federal Ministry of Environment Housing and Urban Development, Abuja.

Coe, M. (2001). Shrinking Lake Chad NASA. University of Wisconsin. USA.

Dami, A. (2008). Geographic Information System (GIS) based predictive study of environmental change in the Nigerian's section of the Chad Basin. Ph.D. thesis. Unpublished. OAU Ile-Ife. 
Duraiappah, A. (1996). Poverty and Environmental Degradation: A Literature Review and analysis. International Institute for Environmental Development IIED CREED Working paper series no.8.41p.

IPCC. (2001). Climate change 2001: Impacts, Adaptation, and Vulnerability. Published for the Intergovernmental Panel on Climate Change. Cambridge University press.

LCBC. (2007). Regional Roundtable on sustainable development of the Lake Chad Basin. University of Maiduguri, Nigeria.

LCBC. (2008). Saving Lake Chad. Proceedings of Sirte Roundtable, Libya, 17th December 2008 International Commission on Irrigation and Drainage (ICID) 48 Nyaya Marg, Chanakyapuri, New Delhi 110021.

NASA. (2001). A shadow of a lake: Africa's disappearing Lake Chad. NASA Goddard Space Center on Line News Release (GSFC).

NPC (2006). The Nigerian National Population Census 2006. Nigeria population Commission, Nigeria.

Nyong, A. (2001). Livelihood Strategies among Poor Rural Households to Cope with Droughts in Northern Nigeria. UNFCCC Expert Workshop on Local Coping strategies and Technologies for Adaptation. Delhi, India. 12-13 November 2001.

Nyong, A. Adesina, F \& Elasha Osman, B. (2007). The value of indigenous knowledge in climate change mitigation and adaptation strategies in African Sahel. Mitig Adapt Strat Glob Change, 12, 787-797. doi:10.1007/s1 1027-007-9099-0, http://dx.doi.org/10.1007/s11027-007-9099-0

Nyong, A., Dabi D. Adepetu, A. Berthe, A. \& Ihemegbulem, V. (2008). Vulnerability in the sahelian zone of northern Nigeria. climate change and vulnerability. Earthscan.

Perkins, J.S. \& Thomas, D.S.G. (1993). Spreading Deserts or spatially confined Environmental Impacts? Land Degradation and Cattle Ranching in Kalahari Desert of Botswana. Land Degradation and Rehabilitation 4, 179-194. doi:10.1002/ldr.3400040307, http://dx.doi.org/10.1002/ldr.3400040307

Thambyahphillay, G.G.R. (1987). Meteorological and Climatological Perspective of Drought and desertification in the Lake Chad Basin of Sahelo-Soudan Nigeria. Paper presented to the Chad Basin Commission's International Seminar on Water Resources in the Lake Chad Basin: Management and Conservation, N'Djamena, Republic of Chad, 3rd-5th June, 1987.

Workineh, K. (2007). Climate Change Impacts and indigenous coping strategies in Africa. Paper prepared for the international conference on riding on a moral storm: The challenge of climate change: Science - Economics -Ethics- Politics. University of Wales, Cardiff. Washington, D.C.

Young, A. (2000). Land resources now and for the future. Cambridge University Press.

Table 1. Coping strategies in conditions of extreme events

\begin{tabular}{|l|l|l|}
\hline Periods & Frequency & Percent \\
\hline Fall back on stored harvests & 125 & 24.7 \\
\hline Engage in fishing (farmer) & 87 & 17.2 \\
\hline Engage in rearing animals (farmer) & 111 & 21.9 \\
\hline Migrate to nearby country for food (during dry season period) & 21 & 4.1 \\
\hline Buying and selling non agricultural goods (during dry season period) & 90 & 17.8 \\
\hline Nothing & 38 & 7.5 \\
\hline Others specify (handcraft such as weaving and mat making) & 35 & 6.9 \\
\hline Total & 507 & 100 \\
\hline
\end{tabular}

Source: Field survey, 2007 
Table 2. Sources of water for farming

\begin{tabular}{|l|l|l|}
\hline Sources & Frequency & Percent \\
\hline Lake built for irrigation during dry season & 35 & 6.9 \\
\hline Raining season & 122 & 24.1 \\
\hline Both & 344 & 67.9 \\
\hline Other specify (small ponds and wells) & 6 & 1.2 \\
\hline Total & 507 & 100 \\
\hline
\end{tabular}

Source: Field survey, 2007

Table 3. Seasonality in the usage of water

\begin{tabular}{|l|l|l|}
\hline Periods & Frequency & Percent \\
\hline Dry season only & 63 & 12.4 \\
\hline Rain season only & 69 & 13.6 \\
\hline Rain and dry seasons & 370 & 73.8 \\
\hline Other specify & 5 & 1.0 \\
\hline Total & 507 & 100 \\
\hline
\end{tabular}

Source: Field survey, 2007

Table 4. Received assistance when there was crop failure

\begin{tabular}{|l|l|l|}
\hline Response & Frequency & Percent \\
\hline Received assistance when crop failed & & \\
\hline Yes & 116 & 22.9 \\
\hline No & 391 & 77.1 \\
\hline Types of assistance & & \\
\hline Money & 31 & 26.7 \\
\hline Offered grain & 76 & 65.5 \\
\hline Other specify & 9 & 7.8 \\
\hline Total & 507 & 100 \\
\hline
\end{tabular}

Source: Field survey, 2007 
Table 5. Awareness of the People of Government's programme and their sources

\begin{tabular}{|c|c|c|}
\hline Issues/Response & Frequency & Percentage \\
\hline \multicolumn{3}{|c|}{ 1. Awareness of existence of government programme to address declining water level } \\
\hline Yes & 173 & 34.1 \\
\hline No & 297 & 58.6 \\
\hline Don’t know & 37 & 7.3 \\
\hline \multicolumn{3}{|c|}{ 2. Awareness of plan by government to restore the basin } \\
\hline Yes & 309 & 61.0 \\
\hline No & 198 & 39.1 \\
\hline \multicolumn{3}{|c|}{ 3. Sources of awareness of government intervention programme } \\
\hline Heard from radio & 257 & 50.7 \\
\hline I heard from people & 36 & 7.1 \\
\hline Other sources & 163 & 32.2 \\
\hline \multicolumn{3}{|c|}{ 4. Source of funding inter-basin water transfer } \\
\hline Nigerian government & 309 & 61.0 \\
\hline Foreign government & 92 & 18.1 \\
\hline Non-Governmental organization & 68 & 13.4 \\
\hline Local communities & 37 & 7.3 \\
\hline Other specify & 1 & 0.2 \\
\hline Total respondents in each case above & 507 & 100 \\
\hline
\end{tabular}

Source: Field survey, 2007

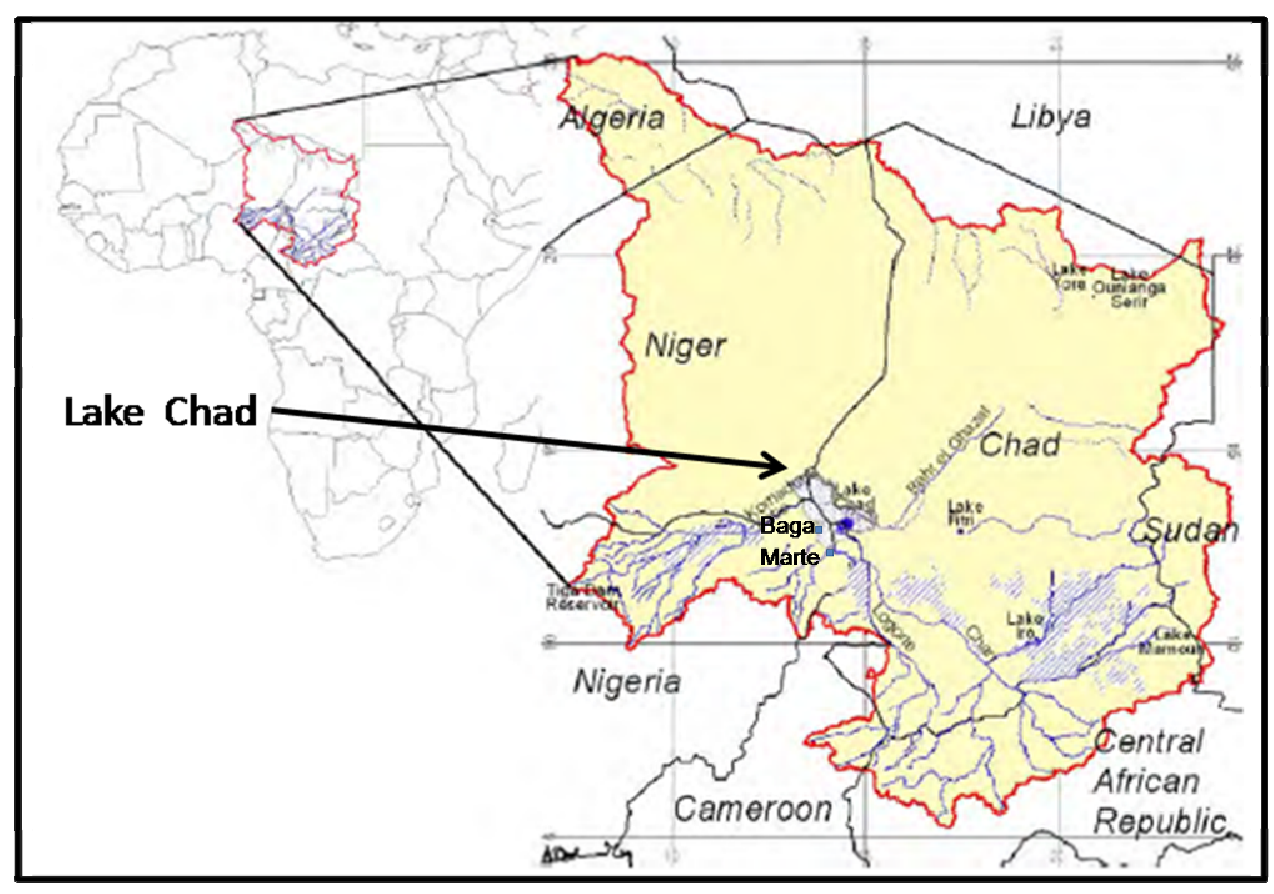

Figure 1. Location of Study Area, in Lake Chad basin (Adopted from LCBC, 2007) 

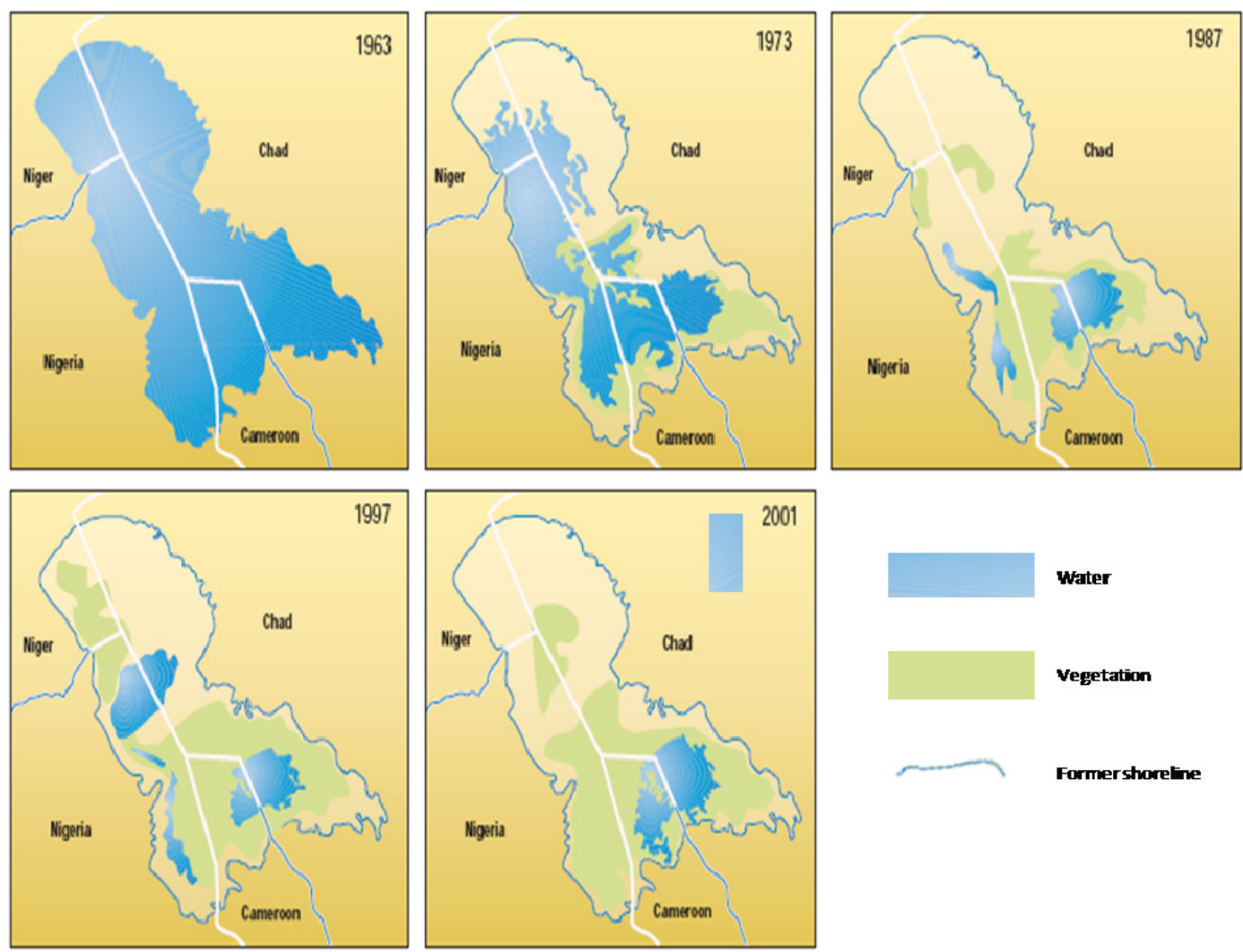

Soure: UNEP 2002, data from CSFC2001

Figure 2. The changing quantity of water in the Lake Chad between 1963 and 2001 (AMCEN/UNEP, 2006) 